\title{
Short Communication: \\ Community of phytoplankton in peatland canal, Riau, and wet dune slacks of Parangtritis, Yogyakarta, Indonesia
}

\author{
ANNISA MAWARNI, FIRDA N.N. AZIZAH, HENI W. SARTIKA, SUWARNO HADISUSANTO", \\ DWINDA M. PUTRI, AKBAR REZA \\ Faculty of Biology, Universitas Gadjah Mada. Jl. Teknika Selatan, Sekip Utara, Sleman 55281, Yogyakarta, Indonesia. \\ Tel./fax.: +62-274-546860, `email: suwarnohs@ugm.ac.id, annisa.mawarni@mail.ugm.ac.id
}

Manuscript received: 28 November 2019. Revision accepted: 9 April 2020.

\begin{abstract}
Mawarni A, Azizah FNN, Sartika HW, Hadisusanto S, Putri DM, Reza A. 2020. Short Communication: Community of Phytoplankton in peatland canal, Riau, and wet dune slacks of Parangtritis, Yogyakarta, Indonesia. Biodiversitas 21: 1874-1879. The ecosystems of peatland canal and wet dune slacks have specific characteristics for phytoplankton community. This study aimed to elaborate on the distribution and abundance of phytoplankton community in peatland canal of Sungai Tohor Village, Meranti Islands, Riau and wet dune slacks of Parangtritis, Special Region of Yogyakarta. Phytoplankton was collected using a 2-L modified Van Dorn water sampler. In peatland, canal phytoplankton was sampled at 3 different locations, each with 5 repetitions. Meanwhile, in wet dune slacks, phytoplankton was sampled at 5 locations, each with 3 repetitions. Phytoplankton samples were filtered with Wisconsin plankton-net 120 mesh and fixed with 3 drops of formaldehyde 4\%. The measured physical and chemical factors were air temperature, water temperature, dissolved oxygen, alkalinity, carbon dioxide, $\mathrm{pH}$, depth, transparency, nitrate, sulfate, and phosphate concentration. The results showed that the distribution and abundance of phytoplankton community in wet dune slacks were greater than those of the peatland community. This research found 18 species of phytoplankton in peatland canal, dominated by Synedra acus and 116 species of phytoplankton in wet dune slacks, dominated by Cyclotella meneghiniana.
\end{abstract}

Keywords: Cyclotella meneghiniana, Synedra acus, tropical wetland

\section{INTRODUCTION}

Peatland is formed by the accumulation of animal and plant constituents due to incomplete decomposition caused by anoxic conditions, low decomposability of plant materials, and other complex causes. As a result, peatlands have high acidity and low nutrient availability (Rydin and Jeglum 2006). One of the peatlands in Indonesia is the peatland of Sungai Tohor Village, Meranti Islands, Riau. Water that comes from canal built around peatlands is widely used by the community to carry out daily activities such as bathing and washing. Besides, the community also uses water bodies as a means of transportation in the distribution of sago trees through peat water flows. Another activity carried out by the community in Sungai Tohor Village is sago processing. However, this sago processing waste is dumped directly into the peat stream without any waste treatment.

Meanwhile, dune slack is a basin or valley that lies between the back of the dune where the groundwater is close to the surface. Its condition greatly varies with the seasonal change. During the high rainfall intensity, the dune slack will be flooded by water called wet/humid dune slack (Davy et al. 2006; Houston 2008; Stratford and Rooney 2017). Wet dune slack is a wetland ecosystem in the coastal sandbank system. The hydro-ecological conditions in the dune slack produce a habitat for several species (Pethick 1984; Nature Conservation Committee
2007; Stratford and Rooney 2017). One of the dune slacks in Indonesia is located in Parangtritis Sand Dune, Bantul District, Yogyakarta, Indonesia. The phenomenon of Cempaka tropical cyclone in mid-November 2017 caused very high rainfall intensity in Bantul area, so the dune slack was inundated by water to a depth of approximately one meter. Local communities used this opportunity for tourist attractions, fishing areas, and farming, So, the sustainability of the original ecosystem can be disrupted.

Water is a habitat for phytoplankton that have a role in the nutrient cycle, food chain, and the initial succession of an aquatic ecosystem. Also, phytoplankton can be used as a parameter of water body quality through their response to the physical and chemical properties of the surroundings (Horne and Goldman 1994). Because peatland and wet dune slack have different characteristics, this study examined the differences of phytoplankton communities between the two ecosystems.

\section{MATERIALS AND METHODS}

\section{Study area}

The peatland canal in this study was located in Sungai Tohor Village, Kepulauan Meranti Regency, Riau. It has a length of approximately 4.6 kilometers, with the flow direction from PS1, to PS2 and to PS3. Meanwhile, the wet dune slacks were located in Parangtritis Sand Dune, Bantul 
Regency, Special Region of Yogyakarta. There were 3 sampling sites in peatland canal and 5 sampling sites in wet dune slacks. The sampling sites were chosen based on differences in ambient conditions at each sampling station (Table 1).

\section{Procedures}

Phytoplankton collection

Water samples were collected separately for physicochemical and phytoplankton analyses. Water samples for phytoplankton analysis were taken using a modified 2 L Van Dorn water sampler. The total volume of water needed for one flacon bottle was $10 \mathrm{~L}$. The samples were taken from 3 locations with 5 replicates each in peatland canal, so the total water volume taken at each Peatland Station sampling site was 50 liters. Meanwhile, in wet dune slacks, the water sample taken from 5 locations with 3 replicates each, so the total water volume taken at each Dune Slack Station sampling was 30 liters. The water sample was transferred to a bucket and then filtered with Wisconsin plankton-net 120 mesh. The filtered water sample was then put into a flacon bottle. Fixation was done by giving $4 \%$ formaldehyde in 3 drops. The flacon bottle was then wrapped in plastic and tied with a rubber band.

\section{Physico-chemical parameter measurement}

Physical and chemical parameters were measured directly at each sampling site, including alkalinity, dissolved oxygen level, dissolved $\mathrm{CO}_{2}$ level, water depth, water transparency, water temperature, air temperature, salinity, $\mathrm{pH}$, wind speed, light intensity, nitrate content, sulfate content, phosphate content, and sediment. Meanwhile, sediment samples and water samples for nitrate, phosphate, and sulfate value were taken and analyzed in the laboratory (APHA 1998).

\section{Data analysis}

Phytoplankton samples were observed using SRCC (Sedgewick Rafter Counting Chamber) and a binocular light microscope at magnification of 10x10. Identification was carried out using the books of Edmonson (1959) and Shirota (1966) and then individual counting of each species was done using the total strip counting method. The results of the plankton tabulation were analyzed using Microsoft Office Excel 2007 to determine the value of species density (D).

Table 1. Research stations, sampling sites, their codes, and geographical coordinates.

\begin{tabular}{|c|c|c|c|c|}
\hline Research station & Sampling site no. & Code & Latitude & Longitude \\
\hline \multirow[t]{3}{*}{ Peatland Station } & 1 & PS1 & $00^{\circ} 49^{\prime} 47.8560^{\prime \prime} \mathrm{N}$ & $102^{\circ} 56^{\prime} 03.6960^{\prime \prime} \mathrm{E}$ \\
\hline & 2 & PS2 & $00^{\circ} 50^{\prime} 50.6400^{\prime \prime} \mathrm{N}$ & $102^{\circ} 56^{\prime} 22.5240^{\prime \prime} \mathrm{E}$ \\
\hline & 3 & PS3 & $00^{\circ} 51^{\prime} 34.5960^{\prime \prime} \mathrm{N}$ & $102^{\circ} 56^{\prime} 36.6720^{\prime \prime} \mathrm{E}$ \\
\hline \multirow[t]{5}{*}{ Dune Slack Station } & 1 & DS1 & $08^{\circ} 01^{\prime} 05.8400^{\prime \prime} \mathrm{N}$ & $110^{\circ} 19^{\prime} 08.4600^{\prime \prime} \mathrm{E}$ \\
\hline & 2 & DS2 & $08^{\circ} 01^{\prime} 00.7700^{\prime \prime} \mathrm{N}$ & $110^{\circ} 19^{\prime} 10.1300^{\prime \prime} \mathrm{E}$ \\
\hline & 3 & DS3 & $08^{\circ} 00^{\prime} 57.9600^{\prime \prime} \mathrm{N}$ & $110^{\circ} 18^{\prime} 57.9500^{\prime \prime} \mathrm{E}$ \\
\hline & 4 & DS4 & $08^{\circ} 01^{\prime} 00.6200^{\prime \prime} \mathrm{N}$ & $110^{\circ} 18^{\prime} 56.6000^{\prime \prime} \mathrm{E}$ \\
\hline & 5 & DS5 & $08^{\circ} 01^{\prime} 05.4200^{\prime \prime} \mathrm{N}$ & $110^{\circ} 18^{\prime} 49.3500^{\prime \prime} \mathrm{E}$ \\
\hline
\end{tabular}

\section{RESULTS AND DISCUSSION}

Distribution and abundance of phytoplankton species in peatland canal Sungai Tohor Village, Riau.

The phytoplankton can be grouped into 7 functional groups: pennate diatom, centric diatom, unicellular algae, colonial algae, filamentous algae, dinoflagellate, and chlorophyll-protozoa. This grouping was based on the composition of the pigment, the composition of the cell wall, the motion apparatus, the general structure, and the regulation of energy reserves. The phytoplankton found in peatland canal water samples comprised 18 species, consisting of 8 species of pennate diatom, 3 unicellular algae, 1 filamentous algae, 3 colonial algae, and 3 dinoflagellates. The 18 species were Pinnularia gibba, Cymbella cymbiformis, Navicula cryptocephala, Nitzschia filiformis, Surirella ovalis, Synedra acus, Synedra ulna, Tabellaria fenestrate, Closterium gracile, Staurastrum orbiculare, Staurodesmus incus, Spirogyra protecta, Anabaena circinalis, Merismopedia tenuissima, Pandorina morum, Gonyaulax sp., Gymnodinium aureum, and Peridinium gatunense. The highest abundance and distribution of phytoplankton species at each peatland canal sampling site are shown in Figure 1.

Distribution and abundance of phytoplankton species in wet dune slacks of Parangtritis, Special Region of Yogyakarta.

A total of 116 phytoplankton species belonging to seven groups were found in wet dune slack water samples. The first group, pennate diatom, consisted of 37 species, i.e., Achnanthes conspicua, Amphora cupulata, Aulacoseira granulata, Cocconeis placentula, Cymbella cistula, Cymbela sp., Diatoma elongatum, Diatoma vulgaris, Diatomella balfouriana, Entomoneis alata, Epithemia sp., Eunophora tasmanica, Fragilaria capucina, Fragilaria crotonensis, Gomphonema gracile, Gomphonema sphaerophorum, Hantzschia amphioxys, Navicula cuspidata, Navicula gregaria, Navicula radiosa, Neidium affine, Neidium iridis, Nitzschia exilis, Nitzschia filiformis, Nitzschia recta, Nitzschia sigma, Odontidium mesodon, Pinnularia acrosphaeria, Pinnularia divergens, Pinnularia divergens, Pinnularia viridis, Rhopalodia gibba, Sellaphora laevissima, Sellaphora pupula, Staurosira construens, Surirella elegans, Synedra acus and Synedra ulna. The second group, centric diatom, had only a species, i.e., Cyclotella meneghiniana. 
PS1

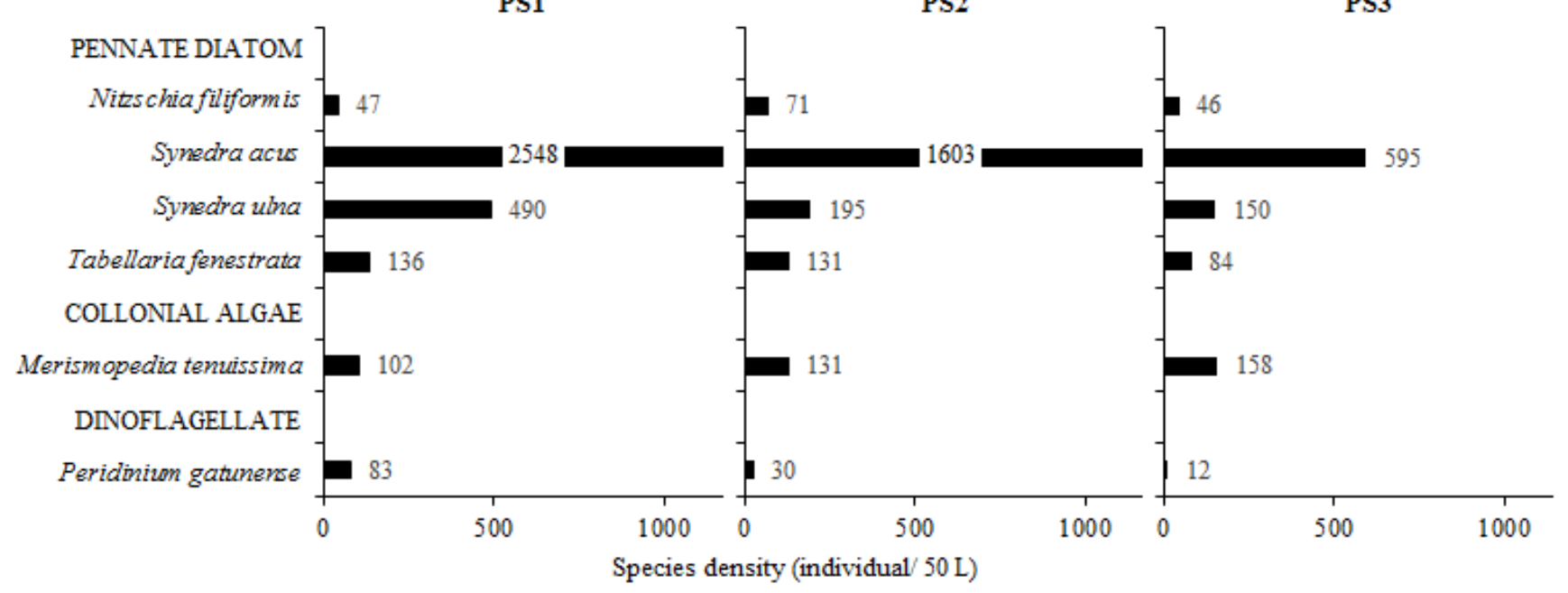

Figure 1. The five highest in distribution and abundance of phytoplankton species in the peatland canal of Sungai Tohor Village, Riau, Indonesia. PS1: Peatland Station 1, PS2: Peatland Station 2, PS3: Peatland Station 3

The third group, unicellular algae, had 23 species, i.e., Chroococcus limneticus, Chroococcus turgidus, Closterium acerosum, Closterium littorale, Coelastrella terrestris, Colacium vesiculosum, Cosmarium botrytis, Cosmarium majae, Cosmarium margaritiferum, Cosmarium protractum, Cosmarium punctulatum, Cosmarium ralfsii, Cosmarium reniforme, Cosmarium striolatum, Cosmarium subspeciosum, Cosmocladium constrictum, Cylindrocystis gracilis, Dissodinium pseudolunula, Euastrum spinulosum, Pleurotaenium sp., Staurastrum avicula, Staurastrum gracile and Staurodesmus dejectus. The fourth group, colonial algae, comprised 28 species, i.e., Asterococcus superbus, Coelastrum sphaericum, Coelosphaerium kuetzingianum, Crucigenia quandrata, Crucigenia tetrapedia, Dictyosphaerium pulchellum, Gloeocapsa gelatinosa, Gloeocapsa sp., Limnococcus limneticus, Lobocystis dichotoma, Merismopedia tenuissima, Microcystis protocystis, Nephrocytium lunatum, Oocystis marssonii, Pandorina morum, Pediastrum duplex, Pediastrum simplex, Planktosphaeria sp., Radiococcus sphaericus, Scenedesmus perforatus, Scenedesmus quadricauda, Sphaerocystis schroeteri, Tetradesmus dimorphus, Tetradesmus obliquus, Volvox sp., Westella botryoides, Willea apiculata and Woronichinia naegeliana. Next, the fifth group, filamentous algae, consisted of 18 species, i.e. Aphanizomenon ovalisporum, Aphanizomenon flos-aquae, Gonatozygon aculeatum, Hyalotheca dissiliens, Hydrodictyon reticulatum, Lyngbya birgei, Mougeotia viridis, Nodularia spumigena, Nostoc linckia, Onychonema laeve, Oogonium crispum, Oscillatoria princeps, Sphaerozosma vertebratum, Spirogyra crassa, Spirulina major, Tribonema minus, Ulothrix sp. and Zygnema sp.

The sixth group, dinoflagellate, had 3 species, i.e., Gonyaulax sp., Peridinium sp. and Prorocentrum redfieldii, while the seventh group, chlorophyll-protozoa, consisted of 6 species, i.e., Colpidium colpoda, Euglena oxyuris, Euglena proxima, Lepocinclis fusiformis, Phacus caudatus and Trachelomonas scabra. The top five species having the highest abundance and distribution at each sampling site are shown in Figure 2.

Differences in the abundance and distribution of phytoplankton in 2 Sampling Stations.

Peatland canal and wet dune slack ecosystems have very different characters (Table 2).

Table 2. Physical and chemical parameters of water at each site

\begin{tabular}{|c|c|c|c|c|c|c|c|c|}
\hline \multirow{2}{*}{ Physical and chemical parameters } & \multicolumn{8}{|c|}{ Mean value/station } \\
\hline & PS1 & PS2 & PS3 & DS1 & DS2 & DS3 & DS4 & DS5 \\
\hline $\mathrm{DO}(\mathrm{ppm})$ & 4.224 & 4.34 & 2.728 & 14.15 & 11.97 & 17.05 & 8.37 & 21.65 \\
\hline Alkalinity (ppm) & 58.8 & 51.2 & 67.2 & 16.67 & 10 & 20 & 118 & 34 \\
\hline $\mathrm{CO}_{2}(\mathrm{ppm})$ & 42.3 & 38.9 & 4.6 & 2.17 & 4.17 & 1.5 & 7 & 0 \\
\hline $\mathrm{pH}$ & 4.04 & 3.86 & 3.92 & 8.67 & 8.53 & 9.13 & 8.1 & 9.43 \\
\hline Water Temperature $\left({ }^{0} \mathrm{C}\right)$ & 27.8 & 28.4 & 27.8 & 35 & 31.67 & 34.5 & 32.17 & 32.17 \\
\hline Air Temperature $\left({ }^{0} \mathrm{C}\right)$ & 31 & 33 & 32 & 31.5 & 34.67 & 36.33 & 33.33 & 28.33 \\
\hline Depth $(\mathrm{m})$ & 0.99 & 1.33 & 1.47 & 0.1 & 0.88 & 0.55 & 0.58 & 0.25 \\
\hline Transparency (m) & 0.72 & 0.765 & 0.41 & 0.1 & 0.74 & 0.55 & 0.58 & 0.25 \\
\hline Nitrate Concentration (mg/L) & 15.01 & 15.51 & 18.04 & $<0.005$ & $<0.005$ & $<0.005$ & $<0.005$ & $<0.005$ \\
\hline Sulfate Concentration (mg/L) & 0.82 & 0.22 & 0.30 & 7.28 & 6.38 & 8.71 & 3.58 & 6.22 \\
\hline Phosphate Concentration (mg/L) & 2.86 & 3.04 & 3.01 & $<0.01$ & $<0.01$ & $<0.01$ & $<0.01$ & $<0.33$ \\
\hline
\end{tabular}

Note: PS: Peatland Station, DS: Dune Slack Station 


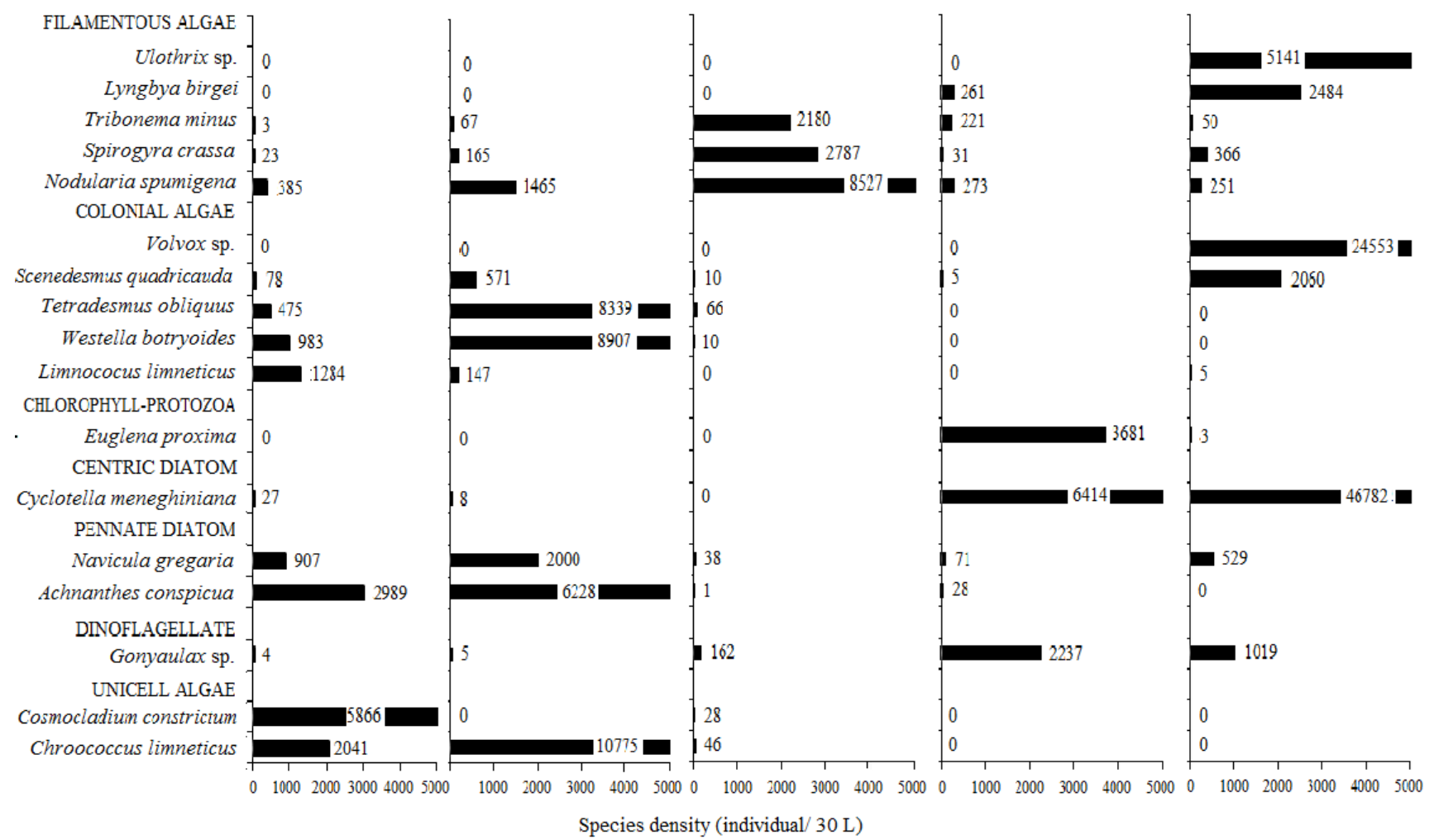

Figure 2. The five highest, in distribution and abundance, of phytoplankton species, in the wet dune slacks of Parangtritis, Special Region of Yogyakarta (DS1 = Dune Slack Station 1, DS2 = Dune Slack Station 2, DS3 = Dune Slack Station 3, DS4 = Dune Slack Station 4, DS5 = Dune Slack Station 5).

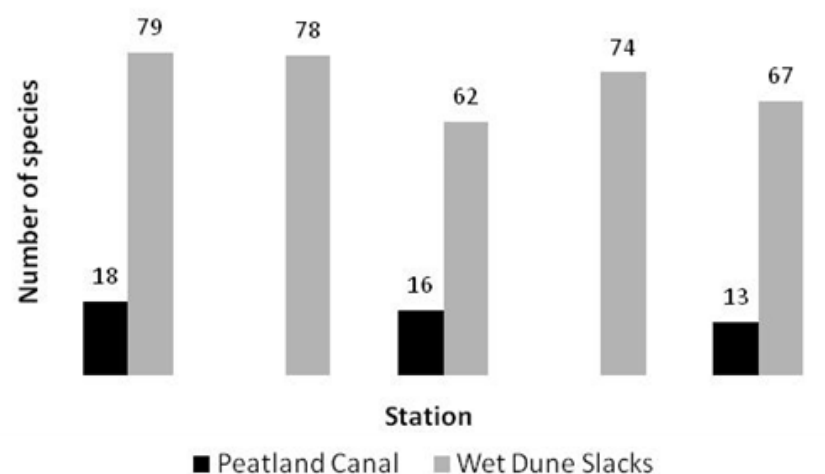

Figure 3. Number of phytoplankton species in the peatland canal, Sungai Tohor Village, Riau and wet dune slacks of Parangtritis, Yogyakarta, Indonesia

\section{Discussion}

Figure 1 shows that there was dominance by the functional group of pennate diatom, namely Nitzschia filiformis, Tabellaria fenestrata, Synedra ulna, and Synedra acus, indicating that pennate diatoms have a greater environmental tolerance than the other functional groups (Azizah 2018). Among these pennate diatoms, Synedra acus had the highest density values in PS1, PS2, and PS3. Synedra acus can obtain sunlight more efficiently than the other phytoplankton species because it is small and flat.
The high density of pennate diatoms in waters results in other functional groups having difficulty getting sunlight as their energy source for photosynthesis, so they had low density due to competition among species (Salmaso 2009).

Merismopedia tenuissima which belongs to the functional group of colonial algae also had high density at all research stations because this species tends to have high abundance in shallow river-floodplains, such as found in peatland canal of Sungai Tohor Village which is 0.99-1.47 meters deep (Table 2). In PS1 Peridinium gatunense was also found, but the number decreased in PS2 and PS3 because this species is sensitive to nitrate concentration (Azizah 2018) which increased from PS1 to PS5 (Table 2).

Figure 2 shows that Achnanthes conspicua was found in DS1 and DS2 because this diatom pennate species is often found abundantly in shallow freshwater and grows optimally at pH 8-9 and alkalinity of 6-10 ppm (Kingston and Sheath 2003; Potapova 2010; Mawarni and Hadisusanto 2019). Cyclotella meneghiniana is the only species of phytoplankton from the centric diatom group found in wet dune slacks of Parangtritis. This species of phytoplankton has no locomotor, so its distribution is influenced by the movement of water, it colonizes and has a wide tolerance for the environment, and, as a result, its distribution is broad. Generally, the diatom groups are intolerant to habitats with high light intensity and temperature, but Cyclotella meneghiniana is able to adapt by slowing the rate of photosynthesis during the day, with 
producing the enzyme of photooxidative destruction (Wetzel 2001).

This species is also commonly found in shallow water habitats with high nutrient levels (Lowe and Kheiri 2015), so it was found abundant in DS4 and DS5 because these locations had high nutrient levels. Cyclotella meneghiniana was not found on DS3 because diatoms were unable to compete with the group of algal filaments that dominated DS3 (Mawarni and Hadisusanto 2019).

Species from unicellular algae groups that have a small size are generally favored by zooplankton and herbivorous fish, so their abundance will decrease if there are many predators. Chroococcus limneticus individuals are sometimes found to colonize the area, so they are larger, able to adapt to conditions of low dissolved oxygen, grow optimally at high temperatures and sufficient light intensity. This group also includes green-blue algae (cyanobacteria) which are not favored by herbivores because of their bad taste and toxic compounds (Murulidhar and Murthy 2015), so they could dominate DS1 and DS2. Volvox sp. was found only in DS5 with a very high density. Filament algae groups generally prefer habitats with high sunlight intensity, so this group was found in DS3. The species that had the highest density was Nodularia spumigena. This species can synthesize peptide, hepatotoxic compounds that can kill fish and zooplankton (dangerous species) (Lassus et al. 2017). Only a few species from the group of chlorophyll dinoflagellates and protozoa were found in wet dune slacks of Parangtritis Sand Dune.

The results showed that phytoplankton species in wet dune slacks were more abundant than in peat canal. Peat water is surface water located in peat areas which are widely distributed in the lowlands of Kalimantan and Sumatra. High color intensity from red to brown, high acidity (low $\mathrm{pH}$ ), and high organic matter content are typical characteristics of peat water (Sartika 2018). This indicates that the peat water ecosystem has extreme environmental conditions. High color intensity prevents sunlight from maximally penetrating the body of water. Also, a high degree of acidity becomes a limiting factor for living phytoplankton. Only certain species can survive in this condition (Murulidhar and Murthy 2015). The sago processing, especially in the Meranti Islands Regency, produces waste, including $17-25 \%$ of bark and $75-83 \%$ of sago pulp (Samosir 2009). The remnants of the treatment were discharged directly into the water body, affecting the quality of the waters. The more organic waste material present in the water, the less dissolved oxygen content available in it, so fewer living creatures can survive (Pethick 1984). The compounds from waste cause the abundant growth of bacteria in the waters, which leads to the abundance of protozoa. Therefore, phytoplankton density was lower in peat water than in wet dune slacks. Wet dune slacks had a $\mathrm{pH}$ of $8-9$, so they had high diversity and abundance of phytoplankton compared to peat swamp canal. The blooming of certain phytoplankton groups in some dune slacks can be caused by the use of wet dune slacks to grow rice (Kingston and Sheath 2003) which increases nutrient input into water bodies (Mawarni and Hadisusanto 2019).

The lack of vegetation coverage in wet dune slacks also causes the high intensity of the light penetrating the body of high water, so the temperature in the waters will be relatively higher. Shallow and clear water at all sampling stations in the wet dune slacks causes the penetration of light through the bottom of the slacks and the absence of thermal stratification. Habitat with optimal light intensity and warm temperatures causes rapid growth of phytoplankton, especially algae filament. The wet dune slacks located on the coast receive strong wind blow which causes the mixing of water in ponds, which is important for the distribution of oxygen, energy, nutrients, sediment material and the distribution of phytoplankton (Hallegraeff et al. 2003; Potapova 2010).

Wet dune slacks in Parangtritis Sand Dune are formed only in certain months during high rainfall intensity and then dry due to evaporation, so the initial success of phytoplankton is determined by the structure, behavior, and physiological adaptation of each species. Some phytoplankton species can change to resting stages, producing cysts or spores that can be dispersed and stored in sediments to avoid extreme competition or extreme environmental conditions such as drought (Hallegraeff et al. 2003; Wetzel 2001). Resting phases in phytoplankton will result in decreased metabolic rate, increased food reserves, and increased cell wall resistance (Horne and Goldman 1994; Wetzel 2001; Kozik 2013).

This study concluded that phytoplankton communities in wet dune slacks, Parangtritis, Special Region of Yogyakarta had much higher species richness (116 species) than those in peatland canal in Sungai Tohor Village, Riau (18 species).

\section{ACKNOWLEDGEMENTS}

We acknowledge the assistance of our best colleagues, i.e., Riska Putri Asmawati, Anggraeni Eka Putri, Dinda Hamasiya K.K., Citra Septiani, Basith Kuncoro Adji, Aruna Bagas Kurniadi, and Hana Putra Wicesa. We are also very grateful to Rahmat, Ferdi, and the Head of Parangkusumo Geomaritime Science Park and staff who have assisted in the research process. Lastly, we acknowledge to Alumni Association of the Marine Study Club, Faculty of Biology, Universitas Gadjah Mada, Yogyakarta, Indonesia, and Indonesian Ministry of Research, Technology and Higher Education for research funding support and facilities.

\section{REFERENCES}

APHA. 1998. Standard Methods for Estimation of Water and Wastewater, 20th ed. American Public Health Association, Washington, D.C.

Azizah FNN. 2018. Distribusi dan kemelimpahan fitoplankton di kanal lahan gambut Desa Sungai Tohor, Kabupaten Kepulauan Meranti, Riau. [Thesis]. Universitas Gadjah Mada, Yogyakarta. [Indonesian]

Davy AJ, Hiscock KM, Jones MLM, Low R, Robins NS, Stratford. 2006. Ecohydrological guidelines for wet dune habitats. Environment Agency, UK. 
Edmondson WT. 1959. Fresh-water Biology. 2nd ed. John Wiley \& Sons, Inc. New York.

Hallegraeff GM, Anderson DM, Cembella AD. 2003. Manual on harmful marine microalgae. UNESCO. Paris.

Hausmann K, Hulsmann N. 1996. Protozoology, second edition. Thieme Mudical Publisher, Inc. New York.

Horne AJ, Goldman CR. 1994. Limnology, second edition. McGraw-Hill, Inc., New York.

Houston JA. 2008. Management of natura 2000 habitats, 2190, humid dune slacks. European Commission, Slovakia.

Kingston JC, Sheath RG. 2003. Araphid and monoraphid diatoms: freshwater algae of North America. Academic Press, Cambridge.

Kozik CR. 2013. Phytoplankton life history events: resting stages and physiological cell death. University of Wisconsin, Milwaukee, WI.

Lassus P, Chomérat N, Hess P, Nézan E. 2017. Toxic and harmful microalgae of the world ocean. International Society for the Study of Harmful Algae/ Intergovernmental Oceanographic Commission of UNESCO, Denmark

Lowe R, Kheiri S. 2015. Cyclotella meneghiniana in diatoms of North America. https:/diatoms.org/species/cycloella_meneghiniana

Mawarni A, Hadisusanto S. 2019. Distribusi dan kemelimpahan plankton di wet dune slacks gumuk pasir Parangtritis, Biospecies Journal. 12 (1): 76-89. [Indonesian]

Murulidhar VN, Murthy VNY. 2015. Ecology, distribution, and diversity of phytoplankton in Teetha Wetland, Tumakuru District, Karnataka, India. Intl J Environ Pollut Res 3 (2): 1-12.
Nature Conservation Committee. 2007. Second report by the UK under article 17 on the implementation of the habitats. JNCC. Peterborough. www.jncc.gov.uk/article 17

Pethick J. 1984. An Introduction to Coastal Geomorphology. Edward Arnold, London.

Potapova M. 2010. Platessa conspicua in diatoms of North America. https://diatoms.org/species/platessa_conspicua

Rydin H, Jeglum J. 2006. The Biology of Peatlands. Oxford University Press. New York.

Salmaso N. 2009. Life strategic, dominance patterns and mechanisms promoting species coexistence in phytoplankton communities along complex environmental gradients. Hydrobiologia 502: 13-36.

Samosir A. 2009. Pengaruh tawas dan diatomea (Diatomaceous Earth) dalam proses pengolahan air gambut dengan metode elektrokoagulasi. [Thesis]. North Sumatra University, Medan. [Indonesian]

Sartika HW. 2018. Komposisi dan kemelimpahan zooplankton di rawa gambut Desa Sungai Tohor, Kabupaten Kepulauan Meranti, Riau. [Thesis]. Universitas Gadjah Mada, Yogyakarta. [Indonesian]

Shirota A. 1966. The plankton of South Vietnam: freshwater and marine plankton. Overseas Technical Cooperation Agency. Japan

Stratford C, Rooney P. 2017. Coastal dune slack hydro-ecology. J Coast Conserv 21: 573-576.

Wetzel RG. 2001. Limnology Lake and River Ecosystem. Academic Press. California. 